\title{
Very wide-bandgap nanostructured metal oxide materials for perovskite solar cells
}

\author{
L. L. Larina ${ }^{1}$, O. V. Alexeeva ${ }^{1}$, O. V. Almjasheva ${ }^{2}$, V.V. Gusarov ${ }^{3}$, S. S. Kozlov ${ }^{1}$, \\ A. B. Nikolskaia ${ }^{1}$, M. F. Vildanova ${ }^{1}$, O. I. Shevaleevskiy ${ }^{1}$ \\ ${ }^{1}$ Department of Solar Photovoltaics, Institute of Biochemical Physics RAS, \\ Kosygin St. 4, Moscow, 119334, Russia \\ ${ }^{2}$ St. Petersburg Electrotechnical University “LETI”, Professora Popova St. 5, Saint Petersburg, 197376, Russia \\ ${ }^{3}$ Ioffe Physical-Technical Institute RAS, Politekhnicheskaya St. 26, Saint Petersburg, 194021, Russia \\ shevale2006@yahoo.com, almjasheva@mail.ru,victor.v.gusarov@gmail.com
}

PACS 73.63.Bd

DOI 10.17586/2220-8054-2019-10-1-70-75

Very wide-bandgap undoped and $\mathrm{Y}_{2} \mathrm{O}_{3}$-doped $\mathrm{ZrO}_{2}$ nanoparticles were synthesized and their structural, optical, morphological and energy characteristics were investigated. It was found that the bandgap value in $\mathrm{ZrO}_{2}$ decreases with $\mathrm{Y}_{2} \mathrm{O}_{3}$ doping. The developed materials were used for fabrication of nanostructured photoelectrodes for perovskite solar cells (PSCs) with the architecture of glass/FTO/ZrO $2_{2}$ $\mathrm{Y}_{2} \mathrm{O}_{3} / \mathrm{CH}_{3} \mathrm{NH}_{3} \mathrm{PbI}_{3}$ /spiro-MeOTAD/Au. The power conversion efficiency in the PSCs based on $\mathrm{ZrO}_{2}-\mathrm{Y}_{2} \mathrm{O}_{3}$ photoelectrodes was significantly higher than that for undoped $\mathrm{ZrO}_{2}$ photoelectrodes. We have found that nanostructured layers, based on very wide-bandgap materials could efficiently transfer the injected electrons via a hopping transport mechanism.

Keywords: nanostructures, $\mathrm{ZrO}_{2}$, thin films, semiconductors, solar photovoltaics, perovskite solar cells.

Received: 10 November 2018

Revised: 18 January 2019

\section{Introduction}

Nanostructured materials are widely used for the development of next-generation solar cells (SCs) since they enable fabrication of high efficiency and low-cost devices which are promising for mass production of photovoltaic technologies [1,2]. Recently, a considerable interest is focused on inorganic-organic metal halide perovskite solar cells (PSCs) in which the record power conversion efficiency (PCE) exceeded $22 \%$ [3] and reached $27.3 \%$ in perovskite-silicon tandem solar cell [4]. PSC's architecture comprises a mesoscopic layer of metal-oxide nanoparticles on a conductive substrate, which plays a role of the electron-conductive photoelectrode, a perovskite $\left(\mathrm{CH}_{3} \mathrm{NH}_{3} \mathrm{PbI}_{3}\right)$ layer deposited on top of the photoelectode, a hole-conductive layer and a metallic counter electrode $[5,6]$.

One of the key components of the PSC is an electron-conductive photoelectrode, which consists of metal oxide semiconductor nanoparticles organized in a mesoscopic architecture. Nanostructured layers of titanium dioxide $\left(\mathrm{TiO}_{2}\right)$ with the band gap $\left(E_{g}\right)$ of $3.0-3.2 \mathrm{eV}$ are generally used as photoelectrodes in PSCs $[7,8]$. At the same time, some other wide-bandgap materials were also successfully used in photoelectrodes [9]. The application of a very wide-bandgap metal oxide, such as $\mathrm{ZrO}_{2}$ with $E_{g} \sim 5.7 \mathrm{eV}$, is of special interest for this purpose [10]. Condensed layers of wide-bandgap materials are dielectrics with insulator type conductivity behavior and can't be used as a conductive medium. However, their analogs with nanostructured morphology demonstrate high electronconductive abilities, due to the large concentration of the nanoparticle surface defects. A number of publications confirmed that in nanostructured systems with $E_{g}>5 \mathrm{eV}$, the effective transfer of the injected electrons was observed, while the density of the electrons in the conduction band was negligible [9]. Charge transport through the nanostructured layer can be realized on the basis of a hopping conduction mechanism through localized states within forbidden zone [10].

The formation of crystal phase and morphology in $\mathrm{ZrO}_{2}$ as well as optical and electrical properties of $\mathrm{ZrO}_{2}$ nanoparticles strongly depend on the synthesis conditions [11]. A significant advantage of $\mathrm{ZrO}_{2}$ material is its ability to be doped with yttrium oxide $\left(\mathrm{Y}_{2} \mathrm{O}_{3}\right)$, which allows one to vary the optoelectronic characteristics of $\mathrm{ZrO}_{2}-\mathrm{Y}_{2} \mathrm{O}_{3}$-based nanostructured systems. Doping with rare-earth metals or niobium (Nb) allows to significantly improve the transport characteristics of the photoelectode and to increase the PCE of the PSCs [12,13]. Previously reports of PSCs fabricated using undoped $\mathrm{ZrO}_{2}$-based photoelectode have been made [14]. In this work, we have synthesized $\mathrm{ZrO}_{2}$ nanoparticles and yttrium oxide doped $\mathrm{ZrO}_{2}-\mathrm{Y}_{2} \mathrm{O}_{3}$ systems which were used for fabrication of the nanostructured electron-conductive photoelectrodes for PSCs. Using the developed $\mathrm{ZrO}_{2}-\mathrm{Y}_{2} \mathrm{O}_{3}$-based photoelectrodes, we have prepared a series of PSCs and provided comparative measurements of the main photovoltaic parameters. 


\section{Experimental}

\subsection{Materials and samples preparation}

Nanocrystalline zirconium dioxide was prepared by hydrothermal treatment of zirconium oxyhydroxide precipitated from a solution of $\mathrm{ZrOCl}_{2}$ (chemical pure grade) with concentrated aqueous $\mathrm{NH}_{4} \mathrm{OH}$. Hydrothermal treatment was performed at $T=250{ }^{\circ} \mathrm{C}$ and $P=70 \mathrm{MPa}$ over $4 \mathrm{~h}$. The $\mathrm{Y}_{2} \mathrm{O}_{3}$-doped $\mathrm{ZrO}_{2}$ nanoparticles were obtained by hydrothermal treatment of co-precipitated zirconium and yttrium hydroxides from solutions of the corresponding metal salts. The conditions of hydrothermal treatment were chosen according to the data in [11] and corresponded to complete dehydration of zirconium hydroxide.

To fabricate a nanostructured photoelectrode based on $\mathrm{ZrO}_{2}-\mathrm{Y}_{2} \mathrm{O}_{3}$ system, we utilized a known technique; pastes from $\mathrm{ZrO}_{2}$ and $\mathrm{ZrO}_{2}-\mathrm{Y}_{2} \mathrm{O}_{3}$ nanopowders were prepared in organic solvent [6]. The photoelectodes were formed by depositing the pastes on the glass substrates with a conductive FTO coating. The $\mathrm{ZrO}_{2}$ and $\mathrm{ZrO}_{2}-\mathrm{Y}_{2} \mathrm{O}_{3}$ layers with a thickness of about $200 \mathrm{~nm}$ were deposited using spin-coating method, followed by sintering at $500{ }^{\circ} \mathrm{C}$ for $30 \mathrm{~min}$.

The PSC fabrication process was provided under ambient conditions with high humidity $(\sim 50-60 \%)$ using a one-step method described previously [15]. During the fabrication process, $\mathrm{ZrO}_{2}$-based photoelectodes were first coated with a photosensitive perovskite $\left(\mathrm{CH}_{3} \mathrm{NH}_{3} \mathrm{PbI}_{3}\right)$ layer, obtained from lead iodide and methylammonium iodide precursor solutions, followed by depositing a layer of spiro-MeO-TAD as a hole-transporting material [7,14]. The PSC fabrication process was completed by thermal evaporation of conductive Au contacts with a thickness of $50 \mathrm{~nm}$ using vacuum system VUP-4. As a result, we have prepared PSCs with a device architecture of glass/FTO/ZrO $\mathrm{Zr}_{2}-\mathrm{Y}_{2} \mathrm{O}_{3} / \mathrm{CH}_{3} \mathrm{NH}_{3} \mathrm{PbI}_{3}$ /spiro-MeOTAD/Au, in which the doping content of $\mathrm{Y}_{2} \mathrm{O}_{3}$ was varied from $0 \%$ (undoped system) to 3 and $10 \mathrm{~mol} . \%$.

\subsection{Characterization studies}

The structure and composition of nanostructured $\mathrm{ZrO}_{2}-\mathrm{Y}_{2} \mathrm{O}_{3}$ system were determined by X-ray diffraction (XRD) analysis in the $13-65^{\circ}$ range ( $\mathrm{Cu} \mathrm{K} \alpha$ radiation) using Rigaku Corporation SmartLab 3 diffractometer. The optical properties were investigated using UV-vis double-beam spectrophotometer Shimadzu 3600 with an integrating sphere ISR-3100 (Shimadzu, Japan), followed by an analysis of diffuse reflection spectra over a wavelength range $200-900 \mathrm{~nm}$. The morphology of the films was investigated using dual-beam scanning electron microscope (SEM) Helios NanoLab 660 (FEI, USA).

The measurements of the photovoltaic parameters for PSCs were provided under standard illumination conditions (AM1.5G) with $P_{I N}=1000 \mathrm{~W} / \mathrm{m}^{2}$ by recording the current-voltage characteristics (J-V) using Abet Technologies Solar Simulator (Abet, USA) as a light source and Keithley 4200-SCS Parameter Analyzer (USA) for recording the current-voltage characteristics $(\mathrm{J}-\mathrm{V})$. The PCE $(\eta)$ of the PSC was calculated from the J-V data using the known formula:

$$
\eta=\frac{J_{S C} \cdot V_{O C} \cdot F F}{P_{I N}} \cdot 100 \%
$$

where $J_{S C}$ - short-circuit current density, $V_{O C}$ - open-circuit voltage, $F F$ - fill factor and $P_{I N}-$ light intensity of solar radiation.

\section{Results and discussion}

In Fig. 1, we present comparative data of XRD patterns for the powders of undoped $\mathrm{ZrO}_{2}$ nanoparticles and for $\mathrm{ZrO}_{2}-\mathrm{Y}_{2} \mathrm{O}_{3}$ system with $\mathrm{Y}_{2} \mathrm{O}_{3}$ doping level of 3 and 10 mol.\%. XRD results for the samples, obtained using hydrothermal processing of co-precipitated zirconium and yttrium, reveal the co-existence of tetragonal $(\sim 53 \%)$ and monoclinic $(\sim 47 \%)$ phases in $\mathrm{ZrO}_{2}$ nanoparticles. The addition of 3 mol.\% $\mathrm{Y}_{2} \mathrm{O}_{3}$ to $\mathrm{ZrO}_{2}$ leads to the formation of a predominantly pseudo-cubic modification of $\mathrm{ZrO}_{2}\left(c-\mathrm{ZrO}_{2}\right)$ and a trace amount of the monoclinic modification of $m-\mathrm{ZrO}_{2}$ (up to $5 \%$ ), the addition of $10 \mathrm{~mol} . \% \mathrm{Y}_{2} \mathrm{O}_{3}$ leads to the complete disappearance of $m$ $\mathrm{ZrO}_{2}$. The crystallite size of zirconia phases, determined by the X-ray line broadening method using the Scherrer equation, was found to be 16 and $14 \mathrm{~nm}$ for $m-\mathrm{ZrO}_{2}$ and $t-\mathrm{ZrO}_{2}$, respectively. The obtained results shows that 3 mol. $\% \mathrm{Y}_{2} \mathrm{O}_{3}$ additive does not affect the crystallite size. The addition of 10 mol. $\% \mathrm{Y}_{2} \mathrm{O}_{3}$ decreases the crystallite size down to $5 \mathrm{~nm}$, which can be explained by the formation of the "core-shell" structure in which the shell is enriched with yttria [16].

Figure 2 shows the dependence of the diffuse reflection spectra for the powders of undoped $\mathrm{ZrO}_{2}$ and $\mathrm{ZrO}_{2}-$ $\mathrm{Y}_{2} \mathrm{O}_{3}$ system with $\mathrm{Y}_{2} \mathrm{O}_{3}$ content of 3 and 10 mol.\%. XRD data have shown that yttria doping stabilizes the high-temperature tetragonal $\mathrm{ZrO}_{2}$ phase. This result revealed that $\mathrm{ZrO}_{2}-\mathrm{Y}_{2} \mathrm{O}_{3}$ samples have a monophase structure and, thus, the semiconductor properties of these materials could be characterized by a direct transition from the 


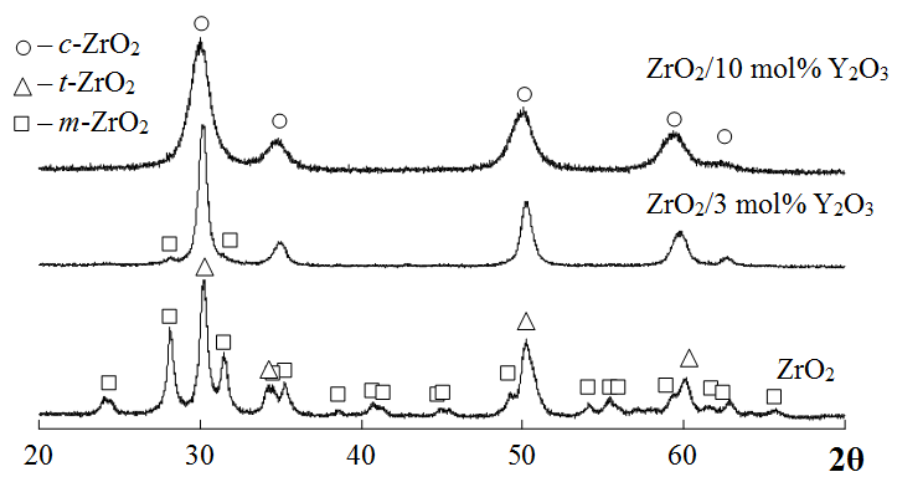

FIG. 1. XRD patterns for $\mathrm{ZrO}_{2}$ nanoparticles with a varied $\mathrm{Y}_{2} \mathrm{O}_{3}$ content

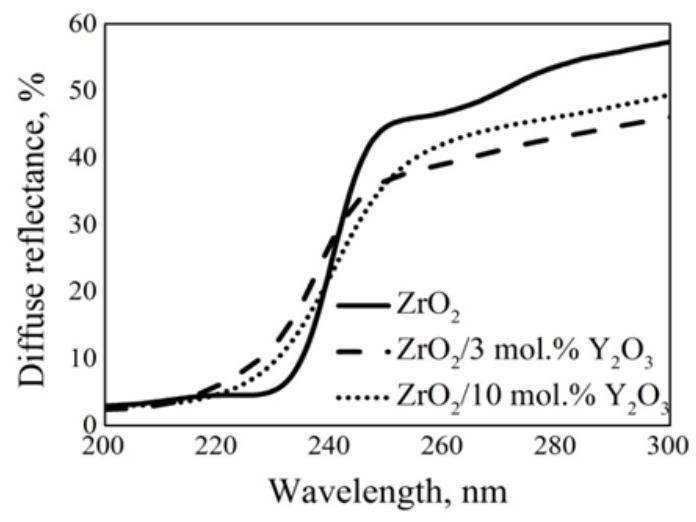

FIG. 2. Diffuse reflectance spectra for the powders of undoped $\mathrm{ZrO}_{2}$ and $\mathrm{ZrO}_{2}-\mathrm{Y}_{2} \mathrm{O}_{3}$ system

valence to the conduction band. Following the Kubelka-Munk theory, the value of the optical energy bandgap $\left(E_{g}\right)$ for direct transitions can be determined from the Tauc plots [17]:

$$
\alpha(h \nu)=C \frac{\left(h \nu-E_{g}\right)^{1 / 2}}{h \nu}
$$

where $a$ - optical absorption coefficient, $C$ - constant, $h \nu$ - photon energy.

The $E_{g}$ values for $\mathrm{ZrO}_{2}$ and $\mathrm{ZrO}_{2}-\mathrm{Y}_{2} \mathrm{O}_{3}$ system were defined with linear extrapolation of $(\alpha h \nu)^{2}$ plots with the photon energy axis (Fig. 3). The results obtained showed that $E_{g}$ value also enhances with the increase of doping concentration from $5.74 \mathrm{eV}$ in $\mathrm{ZrO}_{2}$ to $5.63 \mathrm{eV}$ in $\mathrm{ZrO}_{2}-\mathrm{Y}_{2} \mathrm{O}_{3}$ (3\%). However, in $\mathrm{ZrO}_{2}-\mathrm{Y}_{2} \mathrm{O}_{3}(10 \%)$, the $E_{g}$ value was found to be $5.45 \mathrm{eV}$, which can be explained by a significant decrease of the nanoparticle size for that particular sample, to about $5 \mathrm{~nm}$.

Typical scanning electron microscopy (SEM) surface image of the undoped $\mathrm{ZrO}_{2}$ nanostructured layer deposited on a conductive glass substrate (Fig. 4) indicates the agglomeration of $\mathrm{ZrO}_{2}$ sphere-like crystallites. SEM results show that the average particle size was approximately $30-40 \mathrm{~nm}$. Fig. 5 presents the cross-sectional SEM image of the undoped $\mathrm{ZrO}_{2}$ electron transport layer spin-coated on FTO glass substrate. It is seen that FTO conductive layer is covered with $\sim 200 \mathrm{~nm}$ uniform $\mathrm{ZrO}_{2}$-based mesoscopic layer. Fig. 6 presents $\mathrm{J}-\mathrm{V}$ characteristics, recorded for PSCs under standard illumination AM 1.5G. Photovoltaic parameters for all the investigated PSCs are summarized in Table 1. Comparative studies of the PSCs based on undoped and $\mathrm{Y}_{2} \mathrm{O}_{3}-$ doped $\mathrm{ZrO}_{2}$ photoelectrodes showed that doping leads to the increase of the short-circuit current values and improves the fill factor of the devices, resulting in the increase of total PCE values. The best performance of $11.4 \%$ was obtained for the PSC with $\mathrm{ZrO}_{2}-\mathrm{Y}_{2} \mathrm{O}_{3}(10 \%)$ photoelectrode that significantly exceeds the corresponding value of $5.9 \%$ for PSC based on undoped $\mathrm{ZrO} 2$ photoelectrode.

The performance of $\mathrm{ZrO}_{2}$-based PSCs developed in this study was higher than that in $\mathrm{TiO}_{2}$ based PSCs with much higher observed $V_{O C}$. The major difference between the above mentioned configurations of PSCs concerns the different charge transport mechanisms at the perovskite/photoelectrode interface for $\mathrm{ZrO}_{2}$ and $\mathrm{TiO}_{2}$ electrodes. Fig. 7 presents schematic energy band diagrams demonstrating the energy band structure for PSCs 

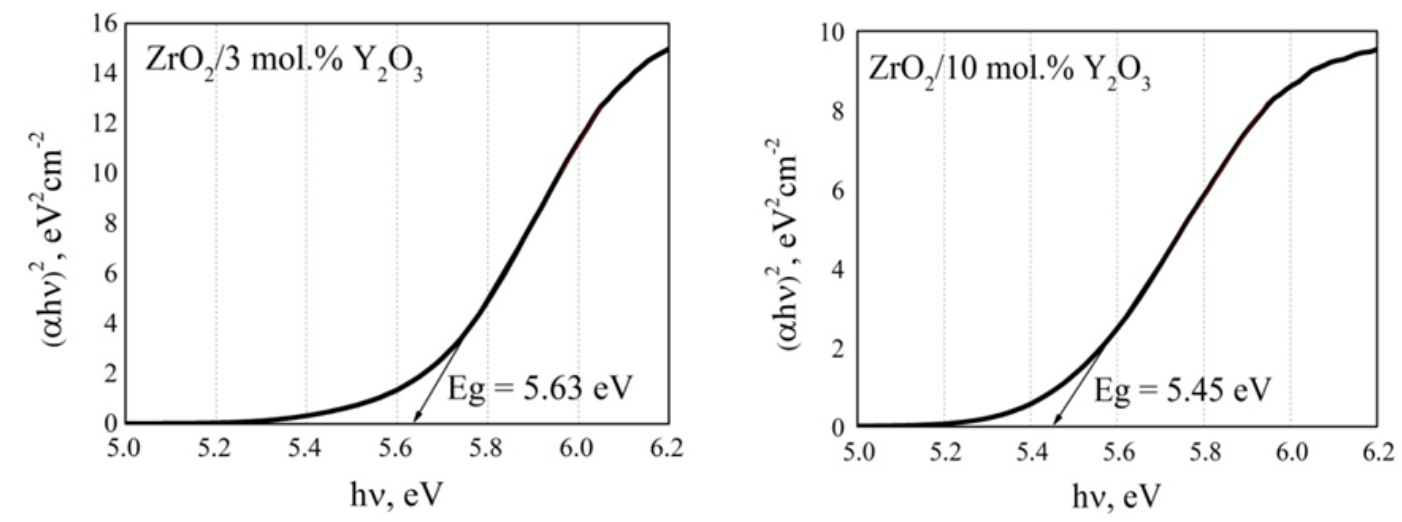

FIG. 3. $E_{g}$ values for $\mathrm{ZrO}_{2}-\mathrm{Y}_{2} \mathrm{O}_{3}$ system extracted from $(\alpha h \nu)^{2}$ vs. photon energy graphics

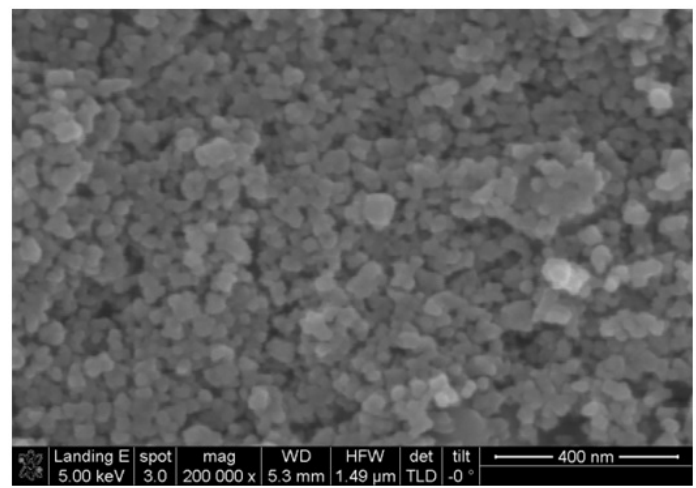

FIG. 4. SEM image of undoped $\mathrm{ZrO}_{2}$ nanostructured layer spin-coated on a conductive glass substrate

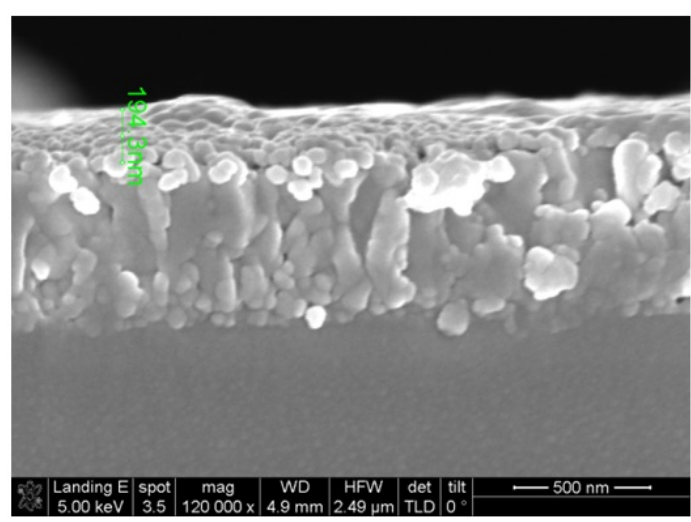

FIG. 5. Cross-sectional SEM image of the $\mathrm{ZrO}_{2}$-based photoelectrode

TABLE 1. Photovoltaic characteristics of $\mathrm{ZrO}_{2}-\mathrm{Y}_{2} \mathrm{O}_{3}$ based PSCs

\begin{tabular}{|c|c|c|c|}
\hline \multirow{2}{*}{ PCE parameters } & \multicolumn{3}{|c|}{ Photoelectrode } \\
\cline { 2 - 4 } & $\mathrm{ZrO}_{2}$ & $\mathrm{ZrO}_{2} / 3$ mol.\% $\mathrm{Y}_{2} \mathrm{O}_{3}$ & $\mathrm{ZrO}_{2} / 10 \mathrm{~mol}_{0} \% \mathrm{Y}_{2} \mathrm{O}_{3}$ \\
\hline \hline$V_{O C}, \mathrm{~V}$ & 0.94 & 1.0 & 1.0 \\
\hline$J_{S C}, \mathrm{~m} / \mathrm{m}^{2}$ & 10.9 & 13.6 & 15.4 \\
\hline$F F$, a.u. & 0.58 & 0.69 & 0.74 \\
\hline$\eta, \%$ & 5.9 & 9.4 & 11.4 \\
\hline
\end{tabular}




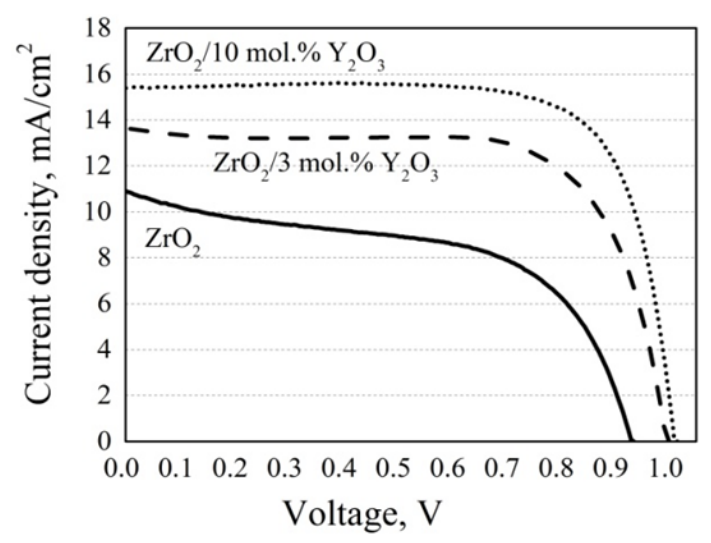

FIG. 6. J-V characteristics of the PSCs based on $\mathrm{ZrO}_{2}-\mathrm{Y}_{2} \mathrm{O}_{3}$ photoelectrodes under simulated AM $1.5 \mathrm{G}\left(1000 \mathrm{~W} / \mathrm{m}^{2}\right)$ irradiance

based on a $\mathrm{ZrO}_{2}$ photoelectrode (Fig. 7(a)) and on traditional $\mathrm{TiO}_{2}$ photoelectrode (Fig. 7(b)). The band diagram in Fig. 7(b) demonstrates that the conduction band edge of perovskite has the energy above the conduction band edge of $\mathrm{TiO}_{2}$ [18] that enables a classic photoexcited electron transfer from the perovskite layer to the $\mathrm{TiO}_{2}$ photoelectrode. Unlike the previously described situation, the conduction band edge of $\mathrm{ZrO}_{2}$ has much higher energy (Fig. 7(a)), leaving the conduction band edge of perovskite far below, which makes it impossible to transfer the electrons from the perovskite to $\mathrm{ZrO}_{2}$ in terms of the classical charge transfer mechanism. It is also known that under ambient temperature, $\mathrm{ZrO}_{2}$ is an insulator with poor carrier transport characteristics and its practical applicability as a charge carrier transporting material is questionable. However, several publications confirmed that the mechanism of charge transport in nanostructured wide-bandgap electrodes, being of primary physical and technical significance, is different from that in the bulk materials [19]. It was also shown that rare earth oxide doping initiates the creation of core-shell structures and results in a high concentration of surface defects [16] that significantly improves the transport characteristics of the mesoscopic photoelectrodes and increases the efficiency of the solar cells [20,21]. The latter is possible due the large concentration of the nanoparticle surface defects. A number of publications confirmed that in nanostructured systems with $E_{g}>5 \mathrm{eV}$, the effective transfer of the injected electrons was observed, while the density of the electrons in the conduction band was negligible [19]. In our study, we observed the effective electron conduction through the nanostructured $\mathrm{ZrO}_{2}$ layer that can be explained on the basis of the hopping conduction mechanism through localized states within forbidden zone of $\mathrm{ZrO}_{2}[10]$.

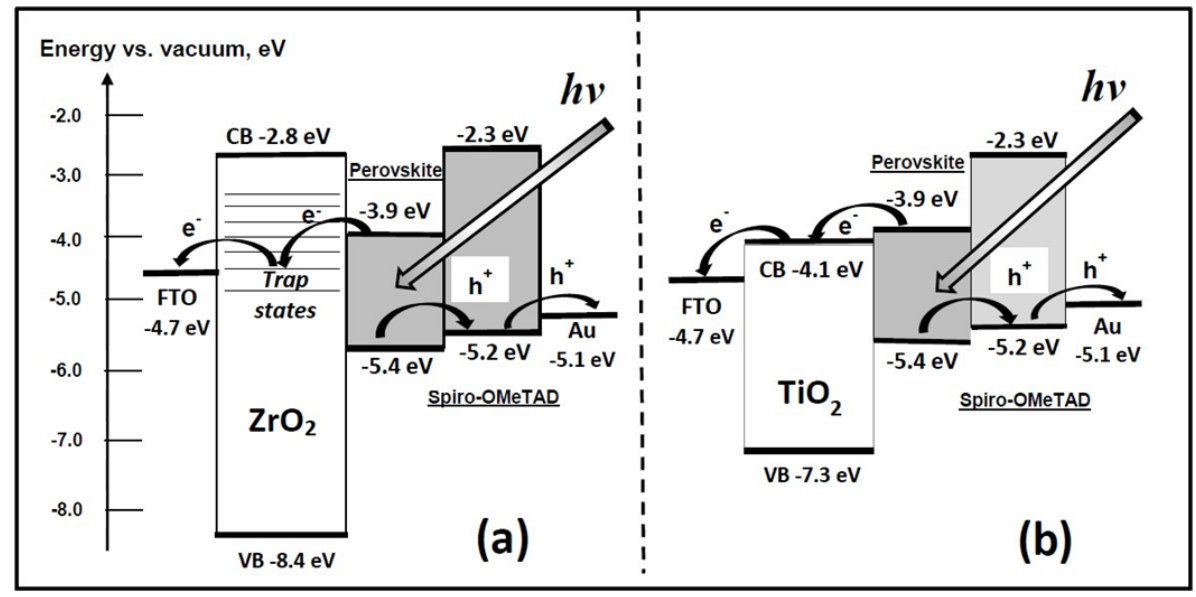

FIG. 7. Schematic energy band diagrams comparing the energy band structures for PSCs based on $\mathrm{ZrO}_{2}$ (a) and $\mathrm{TiO}_{2}$ photoelectrodes (b) 


\section{Conclusions}

As a result, we have developed the technology and provided synthesis of both undoped and $\mathrm{Y}_{2} \mathrm{O}_{3}$-doped $\mathrm{ZrO}_{2}$ nanoparticles for which the structural, optical and energy characteristics were investigated. It was found that the band-gap value in $\mathrm{ZrO}_{2}$ decreases with increased $\mathrm{Y}_{2} \mathrm{O}_{3}$ doping. The developed materials were used for fabrication of nanostructured thin film photoelectrodes for constructing and providing a comparative study of the PSCs with the architecture of glass/FTO/ZrO $\mathrm{Zr}_{2}-\mathrm{Y}_{2} \mathrm{O}_{3} / \mathrm{CH}_{3} \mathrm{NH}_{3} \mathrm{PbI}_{3} /$ spiro-MeOTAD/Au. The power conversion efficiency in the PSCs based on $\mathrm{ZrO}_{2}-\mathrm{Y}_{2} \mathrm{O}_{3}$ photoelectrodes was shown to be significantly higher than that for undoped $\mathrm{ZrO}_{2}$ photoelectrodes. We have found that nanostructured layer, based on very wide-bandgap $\mathrm{ZrO}_{2}$ nanoparticles, could efficiently transfer the injected electrons to the back contact through the hopping transport mechanism via trap states in the forbidden zone of $\mathrm{ZrO}_{2}$. The obtained results demonstrate the possibility of using a very wide-bandgap oxide nanostructured materials with $E_{g}$ values exceeding $5 \mathrm{eV}$ for fabrication electron-conductive layers, including their successful application as mesoscopic photoelectrodes for perovskite solar cells.

\section{Acknowledgements}

This work was supported by the Russian Science Foundation under grant No. 17-19-01776.

\section{References}

[1] Shevaleevskiy O. The future of solar phtovoltics: from physics to chemistry. Pure Appl. Chem., 2008, 80, P. $2079-2089$.

[2] Kuznetsov S.V., Morozov O.A., et al. $\mathrm{Ca}_{1-x-y} \mathrm{Yb}_{x} \operatorname{Pr}_{y} \mathrm{~F}_{2+x+y}$ solid solution powders as a promising materials for crystalline silicon solar energetics. Nanosystems: Phys. Chem. Math., 2018, 9 (2), P. 259-262.

[3] Shi Z., Jayatissa A.H. Perovskite solar cells: from the atomic level to film quality and device performance. Materials, 2018 , 57 (10), P. 2554-2569.

[4] Ho-Baillie A. Perovskites cover silicon textures. Nat. Energy, 2018, 17, P. 751-752.

[5] Marinova N., Tress W., et al. Light harvesting and charge recombination in $\mathrm{CH}_{3} \mathrm{NH}_{3} \mathrm{PbI}_{3}$ perovskite solar cells studied by hole transport layer thickness variation. ACS Nano, 2015, 9, P. 4200-4209.

[6] Vildanova M.F., Kozlov S.S., et al. Niobium-doped titanium dioxide nanoparticles for electron transport layers in perovskite solar cells. Nanosystems: Phys. Chem. Math., 2017, 8 (4), P. 540-545.

[7] Vildanova M.F., Nikolskaia A.B., et al. Novel types of dye-sensitized and perovskite-based ntandem solar cells with a common counter electrode. Tech. Phys. Lett., 2018, 44 (2), P. 126-129.

[8] Kozlov D.A., Lebedev V.A., et al. The microstructure effect on the $\mathrm{Au} / \mathrm{TiO}_{2}$ and $\mathrm{Ag} / \mathrm{TiO}{ }_{2}$ nanocomposites photocatalytic activity. Nanosystems: Phys. Chem. Math., 2018, 9 (2), P. 266-278.

[9] Ganguly A., Nath S.S., Gope G., Choudhury M. CdS quantum dot sensitized zinc oxide based solar cell with aluminum counter electrode. Nanosystems: Phys. Chem. Math., 2017, 8 (6), P. 782-786.

[10] Rath M.S., Ramakrishna G., Mukherjee T., Ghosh H.N. Electron injection into the surface states of $\mathrm{ZrO}_{2}$ nanoparticles from photoexcited quinizarin and its derivatives: effect of surface modification. J. Phys. Chem. B, 2005, 109, P. 20485-20492.

[11] Bugrov A.N., Almjasheva O.V. Effect of hydrothermal synthesis conditions on the morphology of $\mathrm{ZrO}_{2}$ nanoparticles. Nanosystems: Phys. Chem. Math., 2013, 4, P. 810-815.

[12] Almjasheva O.V., Krasilin A.A., Gusarov V.V. Formation mechanism of core-shell nanocrystals obtained via dehydration of coprecipitated hydroxides at hydrothermal conditions. Nanosystems: Phys. Chem. Math., 2018, 9 (4), P. 568-572.

[13] Kolesnik I.V., Lebedev. V.A., Garshev A.V. Optical Properties and photocatalytic activity of nanocrystalline TiO 2 doped by 3 d-metal ions. Nanosystems: Phys. Chem. Math., 2018, 9 (3), P. 401-409.

[14] Bi D., Moon S.J., et al. Using a two-step deposition technique to prepare perovskite $\left(\mathrm{ch}_{3} \mathrm{nh}_{3} \mathrm{pbi}_{3}\right)$ for thin film solar cells based on $\mathrm{ZrO}$ and $\mathrm{TiO}_{2}$ mesostructures. RSC Advances, 2013, 3 (41), P. 18762-18766.

[15] Shevaleevskiy O.I., Nikolskaia A.B., et al. Nanostructured $\mathrm{TiO}_{2}$ Films with a Mixed Phase for Perovskite Solar Cells. Russ. J. Phys. Chem., 2018, 12 (4), P. 663-669.

[16] Almjasheva O.V., Smirnov A.V., et al. Structural features of $\mathrm{ZrO}_{2}-\mathrm{Y}_{2} \mathrm{O}_{3}$ and $\mathrm{ZrO}_{2}-\mathrm{Gd}_{2} \mathrm{O}_{3}$ nanoparticles formed under hydrothermal conditions. Russ. J. Gen. Chem., 2014, 84 (5), P. 804-809.

[17] Tauc J., Grigorovici R.,Vancu A. Optical properties and electronic structure of amorphous germanium. Phys. St. Sol., 1966, 15, P. 627-637.

[18] Kim H.-S., Lee C.-R., et al. Lead iodide perovskites all-solid-state submicron thin film mesoscopic solar cell with efficiency exceeding 9\%. Sci. Rep., 2012, 2, 591.

[19] Oum K., Lohse P.W., et al. Photoinduced ultrafast dynamics of the triphenylamine-based organic sensitizer $\mathrm{D}_{35}$ on $\mathrm{TiO}_{2}$, $\mathrm{ZrO}_{2}$ and in acetonitrile. Phys. Chem. Chem. Phys., 2013, 15, P. 3906-3916.

[20] Nikolay T., Larina, L., Shevaleevskiy O., Ahn B.T., Electronic structure study of lightly Nb-doped $\mathrm{TiO}_{2}$ electrode for dye-sensitized solar cells. Energ. Environ. Sci., 2011, 4, P. 1480-1486.

[21] Kozlov S., Nikolskaia A., et al. Rare-earth and $\mathrm{Nb}$ doping of $\mathrm{TiO}_{2}$ nanocrystalline mesoscopic layers for high-efficiency dye-sensitized solar cells. Phys. St. Sol. A, 2016, 213, P. 1801-1806. 